\title{
Systemic steroids in COPD-the beauty and the beast
}

\author{
Claus F Vogelmeier ${ }^{1,2}$
}

The recommendations regarding the use of systemic steroids in COPD differ substantially depending on the phase of the disease. In moderate and severe acute exacerbations oral steroids are advocated based on the findings of several placebo-controlled trials that have been performed in secondary-care settings: these studies showed that systemic steroids improve lung function, dyspnoea and gas exchange. In addition, steroid use resulted in fewer treatment failures, a lower relapse rate and shorter hospital stays [1-4]. Importantly, giving steroids orally is non-inferior to the i.v. application [5] and an 8-week treatment is not superior to a 2-week therapy [6]. Recently, it could even be shown that 5-day treatment is non-inferior to a 14-day course [7]. In the trial with longer term therapy [6] hyperglycemia requiring treatment was identified as considerable side effect, in the other trials no major adverse events were observed.

In contrast, in stable COPD positive effects of systemic steroids are scarce: there is some evidence that higher doses ( $\geq 30 \mathrm{mg}$ prednisolone/day) may improve lung function over a short period, whereas this was not observed in doses of less than 10-15 mg prednisolone/day [8]. In a 2-year trial with $5 \mathrm{mg}$ prednisolone $+1600 \mu \mathrm{g}$ budesonide/day efficacy regarding lung function decline was not significantly better than budesonide alone [9]. In addition, there are substantial side effect problems. In particular, it is well established that respiratory and peripheral muscle strength [10] are affected. This is caused by a myopathy that is characterized by atrophy and necrosis [11] and may lead to reduced survival. Besides, there is evidence that chronic therapy with systemic steroids is one of the risk factors for the high rate of osteoporosis that is observed in COPD [12].

What does the paper by Horita et al. published in this issue of the journal [13] add to the literature? To my knowledge this is the first analysis that systematically evaluates the effects of systemic steroids on mortality in

\footnotetext{
Correspondence: Claus.Vogelmeier@med.uni-marburg.de

${ }^{1}$ Department of Medicine, Pulmonary and Critical Care Medicine, 35033

Marburg, Germany

${ }^{2}$ Member of the German Center for Lung Research (DZL), University Medical Center Giessen and Marburg, Philipps-Universität Marburg, 35033 Marburg,
} Germany

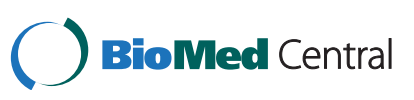

(c) 2014 Vogelmeier; licensee BioMed Central Ltd. This is an Open Access article distributed under the terms of the Creative Commons Attribution License (http://creativecommons.org/licenses/by/4.0), which permits unrestricted use, distribution, and reproduction in any medium, provided the original work is properly credited. The Creative Commons Public Domain Dedication waiver (http://creativecommons.org/publicdomain/zero/1.0/) applies to the data made available in this article, unless otherwise stated. a considerable sample of COPD patients with severe and very severe COPD. The authors analyzed patients $(\mathrm{N}=$ 444) that had been randomized to the conservative treatment arm in the National Emphysema Treatment trial (NETT). They calculated a hazard ratio for death of 1.54 for the steroid user group. Then, in order to make sure that this result was not induced by unidentified confounders they performed a propensity score matching. Based on this analysis the hazard ratio for death in the steroid group was 1.73. Thus, the observed effect seems to be robust and real.

Nevertheless, the authors righteously mention several potential weaknesses of their study: a) it is not prospective, but a prospective trial with this endpoint does not seem feasible, b) the steroid dose was not verified, c) only patients with an FEV1 $\leq 45 \%$ predicted had been included in the NETT trial, but logic tells that systemic steroids should only be considered when all other therapies are not sufficiently effective and it is quite unlikely that this occurs in patients with a moderate lung function impairment. It is quite worrisome though that in the NETT trial only a minority of the patients were treated with long acting bronchodilators.

In summary, the study results support the recommendations in guidelines and strategy documents to stay away from the chronic use of systemic steroids in COPD [14]. As a consequence, in patients in stable condition that are currently treated with systemic steroids this therapy should be tapered/stopped. This can be quite demanding: patients may develop fatigue, low blood pressure, joint pain, weakness and even psychotic symptoms [15]. Importantly, discontinuation of chronic systemic steroid therapy did not result in an increase of COPD exacerbations [16]. There is only one scenario where steroid cessation may be harmful: some patients with an asthma-COPD overlap may profit from longterm use of systemic steroids [17] and may get worse when steroids are stopped.

Based on the cited literature and supported by the findings of Horita et al. [13] there are some simple messages regarding the use of systemic steroids in COPD: a) in moderate or severe acute exacerbations oral steroids 
should be prescribed in a moderate dose $(40 \mathrm{mg}$ prednisolone) for 5 days, b) there is no place for systemic steroids in stable phase COPD, c) in patients treated with systemic steroids outside of an exacerbation steroid treatment should be withdrawn, d) before doing so therapy should be optimized and patients should be reevaluated to make sure that they do not have an asthmaCOPD overlap.

Received: 10 March 2014 Accepted: 25 March 2014

Published: 3 April 2014

\section{References}

1. Thompson WH, Nielson CP, Carvalho P, Charan NB, Crowley JJ: Controlled trial of oral prednisone in outpatients with acute COPD exacerbation. Am J Respir Crit Care Med 1996, 154:407-412.

2. Davies L, Angus RM, Calverley PM: Oral corticosteroids in patient admitted to hospital with exacerbations of chronic obstructive pulmonary disease: a prospective randomised controlled trial. Lancet 1999, 354:456-460.

3. Maltais F, Ostinelli J, Bourbeau J, Tonnel AB, Jacquemet N, Haddon J, Rouleau M, Boukhana M, Martinot JB, Duroux P: Comparison of nebulized budesonide and oral prednisolone with placebo in the treatment of acute exacerbations of chronic obstructive pulmonary disease: a randomized controlled trial. Am J Respir Crit Care Med 2002, 165:698-703.

4. Aaron SD, Vandemheen KL, Hebert P, Dales R, Stiell IG, Ahuja J, Dickinson G, Brison R, Rowe BH, Dreyer J, Yetisir E, Cass D, Wells G: Outpatient oral prednisone after emergency treatment of chronic obstructive pulmonary disease. N Engl J Med 2003, 348:2618-2625.

5. de Jong YP, Uil SM, Grotjohan HP, Postma DS, Kerstjens HA, van den Berg JW: Oral or IV prednisolone in the treatment of COPD exacerbations: a randomized, controlled, double-blind study. Chest 2007, 132:1741-1747.

6. Niewoehner DE, Erbland ML, Deupree RH, Collins D, Gross NJ, Light RW, Anderson P, Morgan NA: Effect of systemic glucocorticoids on exacerbations of chronic obstructive pulmonary disease. Department of veterans affairs cooperative study group. N Engl J Med 1999, 340:1941-1947.

7. Leuppi JD, Schuetz $P$, Bingisser $R$, Bodmer $M$, Briel M, Drescher T, Duerring U, Henzen C, Leibbrandt Y, Maier S, Miedinger D, Müller B, Scherr A Schindler C, Stoeckli R, Viatte S, von Garnier C, Tamm M, Rutishauser J: Short-term vs conventional glucocorticoid therapy in acute exacerbations of chronic obstructive pulmonary disease: the REDUCE randomized clinical trial. JAMA 2013, 309:2223-22331.

8. Walters JA, Walters EH, Wood-Baker R: Oral corticosteroids for stable chronic obstructive pulmonary disease. Cochrane Database Syst Rev 2005, 3, CD005374.

9. Renkema TE, Schouten JP, Koëter GH, Postma DS: Effects of long-term treatment with corticosteroids in COPD. Chest 1996, 109:1156-1162.

10. Decramer M, Lacquet LM, Fagard R, Rogiers P: Corticosteroids contribute to muscle weakness in chronic airflow obstruction. Am J Respir Crit Care Med 1994, 150:11-16.

11. Decramer M, de Bock V, Dom R: Functional and histologic picture of steroid-induced myopathy in chronic obstructive pulmonary disease. Am J Respir Crit Care Med 1996, 153:1958-1964.

12. McEvoy CE, Ensrud KE, Bender E, Genant HK, Yu W, Griffith JM, Niewoehne $D E$ : Association between corticosteroid use and vertebral fractures in older men with chronic obstructive pulmonary disease. Am J Respir Crit Care Med 1998, 157:704-709.

13. Horita N, Miyazawa N, Morita S, Kojima R, Inoue M, Ishigatsubo Y, Kaneko T: Evidence suggesting that oral corticosteroids increase mortality in stable chronic obstructive pulmonary disease. Resp Res 2014, 15:37.

14. Vestbo J, Hurd SS, Agustí AG, Jones PW, Vogelmeier C, Anzueto A, Barnes PJ, Fabbri LM, Martinez FJ, Nishimura M, Stockley RA, Sin DD, Rodriguez-Roisin R: Global strategy for the diagnosis, management, and prevention of chronic obstructive pulmonary disease: GOLD executive summary. Am J Respir Crit Care Med 2013, 187:347-365.
15. Mercadante S, Villari P, Intravaia G: Withdrawal acute psychosis after corticosteroid discontinuation. J Pain Symptom Manage 2007, 34:118-119.

16. Rice KL, Rubins JB, Lebahn F, Parenti CM, Duane PG, Kuskowski M, Joseph AM, Niewoehner DE: Withdrawal of chronic systemic corticosteroids in patients with COPD: a randomized trial. Am J Respir Crit Care Med 2000, 162:174-178.

17. Postma DS, Steenhuis EJ, van der Weele LT, Sluiter HJ: Severe chronic airflow obstruction: can corticosteroids slow down progression? Eur J Respir Dis 1985, 67:56-64.

doi:10.1186/1465-9921-15-38

Cite this article as: Vogelmeier: Systemic steroids in COPD-the beauty and the beast. Respiratory Research 2014 15:38.

\section{Submit your next manuscript to BioMed Central and take full advantage of:}

- Convenient online submission

- Thorough peer review

- No space constraints or color figure charges

- Immediate publication on acceptance

- Inclusion in PubMed, CAS, Scopus and Google Scholar

- Research which is freely available for redistribution 